\title{
Analiza środowiska pracy przy spawaniu metodą MAG elementów ze stali nierdzewnej i stali niestopowej z cynkową powłoką ochronną
}

\author{
Analysis of the work environment during MAG welding \\ of stainless and unalloyed zinc coated steel components
}

\section{Streszczenie}

Procesy spawania metali związane są z powstawaniem substancji niebezpiecznych stwarzających zagrożenie dla zdrowia człowieka, zaklasyfikowanych do jednej z następujących kategorii: toksyczne, szkodliwe, drażniące, uczulające, rakotwórcze, mutagenne. Przy spawaniu elementów wykonanych ze stali nierdzewnej zagrożeniem dla pracowników jest emisja pyłu zawierającego substancje kancerogenne w postaci związków chromu (VI) i związków niklu. Spawanie elementów wykonanych ze stali z powłoką cynkową związane jest z emisją cynku i jego związków, które przy dłużej ekspozycji i niewłaściwej organizacji stanowiska pracy powodują gorączkę metaliczną. W artykule przedstawiono wyniki badań rozpoznawczych emisji zanieczyszczeń powstających przy spawaniu metodą MAG elementów ze stali nierdzewnej ferrytycznej i stali niestopowej z powłoką antykorozyjną ze stopu cynku i żelaza. Przedstawiono również wyniki identyfikacji fazowej i ilościowej analizy fazowej pyłu spawalniczego wydzielającego się podczas spawania blach. Na podstawie badań emisji pyłu i gazów oraz składu chemicznego pyłu przeprowadzono analizę porównawczą warunków pracy przy spawaniu stali nierdzewnej i stali niestopowej w powłoką cynkową.

Słowa kluczowe: środowisko pracy, spawanie, stal nierdzewna, stale z powłokami cynkowymi, dym spawalniczy

\section{Abstract}

Metal welding processes are connected with the occurrence of dangerous substances which can cause hazards to human health. They are classified as one of following categories: toxic, harmful, irritating, allergenic, carcinogenic, mutagenic. Fume forming during welding of stainless steel elements contains carcinogenic substances - chromium(VI) and nickel compounds which cause hazard for workers. Welding of steel elements with protective coatings is connected with the emission of zinc and its compounds, which during long exposure and inappropriate workstation organization, can result in metal fume fever. The article presents the research results of fume and gases emission during MAG welding of ferritic stainless and unalloyed zinc-iron coated steel components. In the article the research results of phase identification and quantitative phase analysis of welding fume are also presented. On the basis of the research results of fume and gases emission and the chemical composition of fume, a comparative analysis of the work conditions during welding of stainless and unalloyed zinc protected coatings steel components was conducte

Keywords: working environment, welding, stainless steel, zinc coated steel, welding fume

\section{Wstęp}

W wytwarzaniu wyrobów spawanych ostatnie lata przyniosły znaczące zmiany w podejściu do zagadnień ochrony środowiska pracy. Wśród pracodawców, kadry inżynierskiej, a także wśród spawaczy i operatorów urządzeń spawalniczych wzrosła świadomość zagrożeń zdrowia i bezpieczeństwa pracy. Działania ukierunkowane na ochronę zdrowia pracowników towarzyszą obecnie wprowadzaniu do praktyki przemysłowej innowacyjnych technologii spawalniczych oraz nowych materiałów podstawowych i dodatkowych.
W przemyśle motoryzacyjnym w celu ochrony pojazdów przed korozją atmosferyczną zachodzi potrzeba stosowania elementów konstrukcyjnych i blach karoseryjnych odpowiednio zabezpieczonych przed korozją, bądź odpornych na korozję. Mogą to być elementy z powłokami na bazie cynku, jak również elementy wykonane z materiałów odpornych na korozję takich jak stale nierdzewne. Spawanie tych materiałów wiąże się z emisją zanieczyszczeń pyłowych i gazowych, które stwarzają zagrożenie dla zdrowia pracowników.

Dr inż. Jolanta.Matusiak, mgr inż. Joanna Wyciślik - Instytut Spawalnictwa, Gliwice.

Autor korespondencyjny/Corresponding author: jolanta.matusiak@is.gliwice.pl 
W artykule przedstawiono wyniki badań emisji zanieczyszczeń powstających przy spawaniu metodą MAG elementów wykonanych ze stali nierdzewnej ferrytycznej i stali niestopowej z powłoką antykorozyjną ze stopu cynku i żelaza. Na podstawie badań emisji pyłu i gazów oraz składu chemicznego pyłu przeprowadzono analizę porównawczą warunków pracy przy spawaniu stali nierdzewnej i stali niestopowej z powłoką cynkową.

\section{Charakterystyka zagrożeń pyłowych i gazowych przy procesach spawania}

Podczas procesu spawania z materiału podstawowego, materiału dodatkowego, powłok ochronnych, gazów osłonowych i otaczającego powietrza, pod wpływem wysokiej temperatury i promieniowania łuku spawalniczego powstaje dym spawalniczy. Dym spawalniczy (aerozol dwufazowy kondensacyjny) jest mieszaniną drobno dyspersyjnych cząstek stałych (pyłu spawalniczego) oraz różnych gazów stanowiących fazę rozpraszającą. Pył spawalniczy powstający w wyniku działania plazmy łuku na materiał podstawowy i dodatkowy składa się z prostych i złożonych tlenków, krzemianów, fluorokrzemianów, fluorków, chromianów, dichromianów oraz węglanów metali $[1,2]$. W łuku zachodzi proces topienia materiałów, ich częściowego odparowania i utleniania par metalu. W atmosferze o niższej temperaturze następuje proces kondensacji i wytworzenie cząstek stałych o różnych wymiarach. Skład chemiczny pyłu spawalniczego jest uzależniony od rodzaju łączonych materiałów, metody i parametrów technologicznych spawania. Podstawowymi składnikami pyłu powstającego przy spawaniu stali niestopowych drutami litymi są żelazo, mangan i ditlenek krzemu, natomiast pył przy spawaniu stali nierdzewnych zawiera dodatkowo związki chromu, niklu, molibdenu i niobu

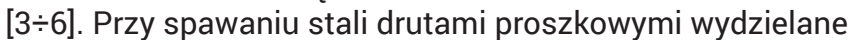
są również związki sodu, potasu, wapnia i magnezu, glinu, tytanu i baru [7]. Źródłem tych pierwiastków jest proszek topnikowy, w skład których wchodzą różne surowce mineralne (np. krzemiany, węglany, fluorki proste i złożone, tlenki metali, szkło sodowe lub potasowe) oraz składniki organiczne. Proces spawania drutami proszkowymi często jest charakteryzowany jako proces niebezpieczny dla pracowników ze względu na toksyczność dymów spawalniczych, a także na bardzo wysoką ich emisję [7]. Źródłem emisji do środowiska pracy par cynku jest obecnie produkcja nowoczesnych konstrukcji i wyrobów spawanych w której stosuje się blachy z powłokami metalicznymi typu: Zn, ZnFe, ZnAl5, ZnNi, ZnAlMg, oraz ze specjalnymi powłokami organicznymi.

Głównymi źródłami emisji gazów przy spawaniu są reakcje termiczne w atmosferze otaczającej łuk, reakcje fotochemiczne w atmosferze otaczającej łuk (emisja promieniowania UV), wypalanie powłok ochronnych oraz proces rozkładu otuliny elektrod i wypełnień drutów proszkowych [4,8]. Zanieczyszczenia gazowe tworzone są głównie przez tlenki azotu $\left(\mathrm{NO}_{\mathrm{x}}\right)$, tlenek węgla $(\mathrm{CO})$ oraz ozon $\left(\mathrm{O}_{3}\right)$. Spawanie blach z powłokami metalowymi, lakierowanymi oraz powłokami dwuwarstwowymi typu metal i powłoka organiczna wiąże się z emisją do środowiska pracy związków chemicznych należących do grupy węglowodorów aromatycznych, $\mathrm{np}$.: benzenu, toluenu, etylobenzenu, ksylenu, fenolu i krezolu oraz wielopierścieniowych węglowodorów aromatycznych (WWA) [9]

\section{Wpływ dymu spawalniczego na organizm człowieka}

Narażenie zawodowe przy procesach spawania na bardzo różnorodne substancje chemiczne powoduje wystąpienie u pracowników szeregu negatywnych skutków zdrowotnych przede wszystkim w obrębie układu oddechowego. Lista schorzeń, które mogą być przyczynowo związane z pracą spawacza obejmuje m.in. gorączkę metaliczną, astmę oskrzelową, przewlekłą obturacyjną chorobę płuc, pylicę, oraz nowotwory złośliwe płuc [10]. Gorączka metaliczna (zwana również gorączką cynkową) jest prawdopodobnie najczęstszym schorzeniem dotyczącym układu oddechowego związanym z narażeniem zawodowym u pracowników przy spawaniu i lutospawaniu [10]. Według źródeł literaturowych z medycyny pracy aż do $30 \%$ spawaczy doświadczyło epizodu tej choroby [10,11]. Przyczyną gorączki metalicznej jest jednorazowa ekspozycja na dymy zawierające tlenki metali - cynku, miedzi, magnezu i glinu. W wyniku narażenia na substancje chemiczne wywołujące gorączkę metaliczną dochodzi do wystąpienia objawów klinicznych; podrażnienia błon śluzowych, kaszlu, bólu w klatce piersiowej, objawów grypopodobnych (osłabienie, bóle mięśniowe, bóle głowy, nudności) i gorączki. Powtarzające się ekspozycje zawodowe na wysokie stężenie tlenku cynku i tlenków miedzi prowadzą do zmian w układzie oddechowym, a gorączka metaliczna uznawana jest za bezpośrednią przyczynę astmy związanej z czynnikami zawodowymi.

Przewlekła obturacyjna choroba płuc (POChP) to schorzenie charakteryzujące się niecałkowicie odwracalnym ograniczeniem przepływu powietrza przez drogi oddechowe. Wykazano, że ekspozycja na takie składniki dymów spawalniczych, jak cynk, glin, mangan, tytan, żelazo i kadm jest związana z szybszym rozwojem przewlekłej obturacyjnej choroby płuc i rozedmy [10]. Badania medyczne spawaczy wykazały, że płuca spawaczy są fizjologicznie o 10 $\div 15$ lat starsze niż płuca osób z grupy zawodowej kontrolnej, nie związanej z procesami spawalniczymi [12]. Narażenie spawaczy na pyły krzemionki w środowisku pracy może być przyczyną wystąpienia pylicy krzemowej (silicosis). Choroby te mogą doprowadzić do trwałego, postępującego upośledzenia czynności układu oddechowego, aż do jego niewydolności. U spawaczy mogą również wystąpić pylice niekolagenowe wywołane wziewnym narażeniem na pył tlenków żelaza (siderosis) [10]. W badaniach emisji zanieczyszczeń przy procesach spawania i procesach pokrewnych dla oceny ryzyka dla zdrowia pracowników ważne jest określenie emisji całkowitej pyłu i gazów oraz rozpoznanie składu chemicznego pyłu z uwzględnieniem również identyfikacji fazowej składników pyłu.

Międzynarodowa Agencja Badań nad Rakiem (IARC - International Agency for Research on Cancer) uznała, że dymy spawalnicze należą do grupy zanieczyszczeń prawdopodobnie kancerogennych. Udowodnione działanie kancerogenne mają takie składniki dymów spawalniczych, jak: nikiel, chro-

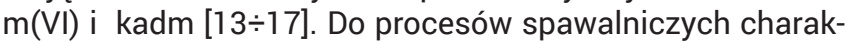
teryzujących się najwyższymi stężeniami w pyle chromu(VI) należą procesy spawania stali nierdzewnych elektrodami otulonymi, drutami proszkowymi oraz drutami litymi w osłonie gazów (MIG/MAG, TIG) [13,17].

\section{Badania własne}

Celem badań było przeprowadzenie analizy porównawczej warunków pracy na stanowiskach spawalniczych przy spawaniu metodą MAG elementów wykonanych ze stali nierdzewnej i stali niestopowej z powłoką cynkową. Analiza warunków pracy dotyczyła narażenia spawaczy na zagrożenia pyłowe i gazowe. Wykonano badania laboratoryjne wielkości emisji pyłu i gazów przy spawaniu profili zamkniętych ze stali nierdzewnej z zastosowaniem drutu elektrodowego litego oraz profili ze stali niestopowej z powłoką ze stopu cynk-żelazo z zastosowaniem drutu proszkowego. Oznaczono 
również skład chemiczny powstającego pyłu. Zakres badań obejmował badania emisji pyłu całkowitego oraz emisji CO i $\mathrm{NO}_{x}$ powstających przy spawaniu łukowym MAG profili o wymiarach $60 \times 60 \mathrm{~mm}$ ze stali nierdzewnej ferrytycznej w gat. X2CrNi12 z zastosowaniem drutu elektrodowego Sandvik 24.13.LSi (ER309LSi) o średnicy 1,0 mm w osłonie mieszaniny $98 \% \mathrm{Ar}+2 \% \mathrm{CO}_{2}$ oraz przy spawaniu metodą MAG profili ze stali niestopowej z powłoką typu cynk-żelazo w gat. E 370 ZF140 z zastosowaniem drutu proszkowego CITOFLUX GALVA (T3T Z M M 1 H15) o średnicy 1,0 mm w osłonie mieszaniny $82 \% \mathrm{Ar}+18 \% \mathrm{CO}_{2}$ [18]. Analizę składu chemicznego pyłu przeprowadzono dla pyłu osadzonego na filtrach pomiarowych na spektrometrze sekwencyjnym wyposażonym w źródło plazmy pionowej typu OES ICP ULTIMA 2 Jobin-Yvon. Identyfikację fazową i ilościową analizę fazową pyłu powstającego przy spawaniu stali X2CrNi12 oraz stali ocynkowanej E 370 ZF 140 wykonano dla próbek pyłu z wykorzystaniem dyfraktometru rentgenowskiego Empyrean, stosując promieniowanie kobaltu w konfiguracji z detektorem Pixcel. Stanowisko doświadczalne do prowadzenia badań emisji zanieczyszczeń przy procesach spawania przedstawiono na rysunku 1 . Parametry spawania metodą MAG stali nierdzewnej i stali niestopowej ocynkowanej dla których prowadzono badania emisji zanieczyszczeń podano $\mathrm{w}$ tablicy $\mathrm{V}$.

Tablica I. Skład chemiczny materiału podstawowego: stal X2CrNi12 Table I. Chemical composition of base material: steel X2CrNi12 (1.4003) (\%)

\begin{tabular}{|c|c|c|c|c|c|c|c|}
\hline \multicolumn{7}{|c|}{ Skład chemiczny gatunku X2CrNi12 (1.4003) (\%) } \\
\hline $\mathrm{C}$ & $\mathrm{Si}$ & $\mathrm{Mn}$ & $\mathrm{P}$ & $\mathrm{S}$ & $\mathrm{N}$ & $\mathrm{Cr}$ & $\mathrm{Ni}$ \\
\hline $\max$ & $\max$ & $\max$ & $\max$ & $\max$ & $\max$ & 10,50 & 0,30 \\
0,03 & 1,00 & 1,50 & 0,040 & 0,015 & 0,030 & $-12,50$ & $-1,00$ \\
\hline
\end{tabular}

Tablica II. Skład chemiczny drutu elektrodowego: Sandvik 2413 LSi (ER 309LSi)

Table II. Chemical composition of electrode wire: Sandvik 2413 LSi (ER 309LSi)

\begin{tabular}{|c|c|c|c|c|c|c|c|}
\hline \multicolumn{1}{|c|}{ Skład chemiczny (\%) } \\
\hline C & Si & Mn & P & S & N & Cr & Ni \\
\hline$<0,025$ & 0,9 & 1,8 & $<0,025$ & $<0,015$ & 0,10 & 23,5 & 13,5 \\
\hline
\end{tabular}

Tablica III. Skład chemiczny materiału podstawowego: stal E 370 ZF140

Table III. Chemical composition of base material: steel E 370 ZF1 40

\begin{tabular}{|c|c|c|c|c|}
\hline \multicolumn{5}{|c|}{ Skład chemiczny gatunku E 370 ZF 140 (\%) } \\
\hline C & Si & Mn & P & S \\
\hline $\max 0,21$ & $\max 0,55$ & $\max 1,60$ & $\max 0,025$ & $\max 0,025$ \\
\hline
\end{tabular}

Tablica IV. Skład chemiczny drutu elektrodowego proszkowego: CITOFLUX GALVA

Table IV. Chemical composition of electrode wire (metal cored): CITOFLUX GALVA

\begin{tabular}{|c|c|c|c|}
\hline \multicolumn{5}{|c|}{ Skład chemiczny (\%) } \\
\hline $\mathrm{C}$ & $\mathrm{Si}$ & $\mathrm{Mn}$ & $\mathrm{Al}$ \\
\hline 0,4 & 1,2 & 0,3 & $<3$ \\
\hline
\end{tabular}

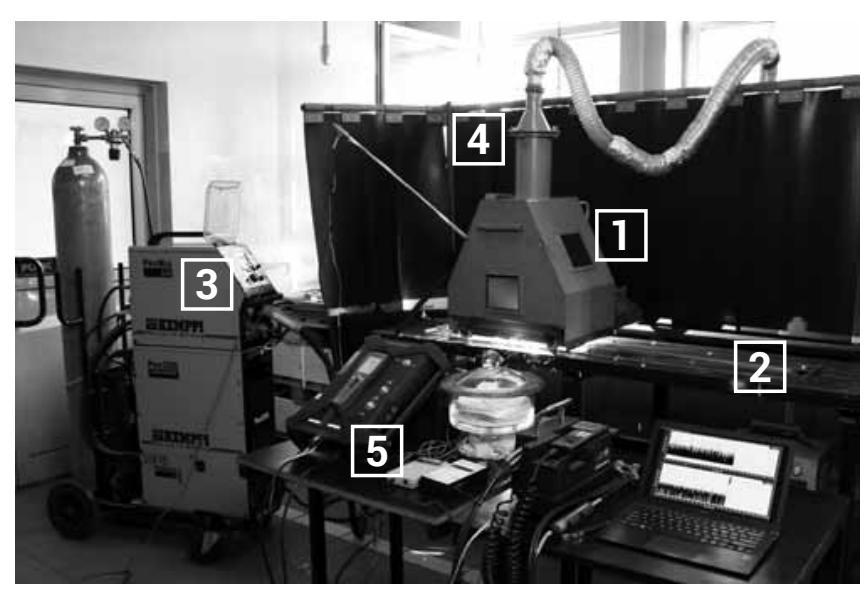

Rys. 1. Stanowisko doświadczalne do badania emisji pyłu i gazów przy spawaniu łukowym metodą MAG: 1. Komora pyłowa; 2 . Stół spawalniczy z zamocowanym elementem; 3 . Urządzenie spawalnicze: PRO EVOLUTION 5200 firmy KEMPPI; 4. Filtr pyłowy; 5. Analizator gazów TESTO 350

Fig. 1. Welding workstation for research emissions of fume and gases during MAG arc welding: 1.Fume chamber; 2 . Welding table and welding element; 3. Welding devices: PRO EVOLUTION 5200 by KEMPPI; 4 . Fume filter; 5 . TESTO 350 analyser of gases

\section{Analiza wyników badania emisji pyłu i gazów powstających przy spawaniu elementów stalowych metodą MAG}

Badania emisji zanieczyszczeń przy spawaniu elementów stalowych metodą MAG wykazały, że rodzaj materiału podstawowego, gatunek drutu elektrodowego oraz parametry spawania mają decydujący wpływ na wielkość emisji pyłu i gazów oraz skład chemiczny powstającego pyłu spawalniczego. Analiza wyników badań wykazała, że emisja czasowa pyłu całkowitego przy spawaniu profili ze stali ocynkowanej w gatunku E370 ZF 140 była w badanym zakresie parametrów prądowych 2-krotnie wyższa w porównaniu do emisji pyłu przy spawaniu profili ze stali nierdzewnej X2CrNi12 (rys.2). Również emisja czasowa gazów przy spawaniu elementów ze stali niestopowej z powłoką cynkową była większa niż przy spawaniu elementów wykonanych ze stali nierdzewnej ferrytycznej. Emisja tlenków azotu

Tablica V. Parametry technologiczne spawania elementów stalowych metodą MAG [18]

Table V. Welding technological parameters during MAG welding steel shapes [18]

\begin{tabular}{|c|c|c|c|c|c|c|}
\hline \multirow{2}{*}{$\begin{array}{c}\text { Materiał } \\
\text { podstawowy }\end{array}$} & \multirow{2}{*}{$\begin{array}{c}\text { Materiał } \\
\text { dodatkowy }\end{array}$} & \multirow{2}{*}{ Gaz osłonowy } & \multicolumn{4}{|c|}{ Parametry technologiczne procesu } \\
\hline & & & I [A] & $\mathrm{U}[\mathrm{V}]$ & $\operatorname{Vdr}[\mathrm{m} / \mathrm{min}]$ & Vsp [mm/min] \\
\hline \multirow{3}{*}{$\begin{array}{l}\mathrm{X} 2 \mathrm{CrNi12} \\
\text { gr. } 2,0 \mathrm{~mm}\end{array}$} & \multirow{3}{*}{$\begin{array}{l}\text { Sandvik } 24.13 . \\
\text { LSi (ER309LSi) } \\
\text { śr. 1,0 mm }\end{array}$} & \multirow{3}{*}{$98 \% \mathrm{Ar}+2 \% \mathrm{CO}_{2}$} & 100 & 17,73 & 5,8 & 380 \\
\hline & & & 150 & 22,03 & 8,5 & 600 \\
\hline & & & 180 & 27,67 & 9,7 & 1110 \\
\hline \multirow{3}{*}{$\begin{array}{c}\text { E } 370 \text { ZF140 } \\
\text { gr. } 3,0 \mathrm{~mm}\end{array}$} & \multirow{3}{*}{$\begin{array}{c}\text { CITOFLUX GALVA } \\
\text { (T3T Z M M } 1 \text { H15) } \\
\text { śr. 1,0 mm }\end{array}$} & \multirow{3}{*}{$82 \% \mathrm{Ar}+18 \% \mathrm{CO}_{2}$} & 150 & 16,27 & 5,4 & 270 \\
\hline & & & 180 & 17,63 & 6,9 & 460 \\
\hline & & & 210 & 20,53 & 7,5 & 560 \\
\hline
\end{tabular}


i tlenku węgla przy spawaniu profili ze stali ocynkowanej E370 ZF 140 była 3,5-krotnie wyższa w porównaniu do emisji przy spawaniu profili ze stali nierdzewnej X2CrNi12.

Analiza chemiczna pyłu powstającego przy spawaniu elementów wykonanych ze stali X2CrNi12 wykazała, że w pyle spawalniczym występują związki chromu, żelaza, manganu, niklu i krzemu (rys. 3). Zawartość poszczególnych związków metali zmieniała się nieznacznie w zależności od parametrów prądowych. W szczegółowej chemicznej analizie fazowej rozpoznano w pyle następujące związki chemiczne: magnetyt $\mathrm{Fe}_{3} \mathrm{O}_{4}$, hematyt $\mathrm{Fe}_{2} \mathrm{O}_{3}$, żelazo metaliczne a-Fe, cząstki stopu $\mathrm{Cr}_{0,18} \mathrm{Fe}_{0,09} \mathrm{Ni}_{0,73} \mathrm{i}$ śladowe ilości tlenku chromu(VI). Dodatkowo wykazano że magnetyt $\left(\mathrm{Fe}_{3} \mathrm{O}_{4}\right)$ jest roztworem stałym zawierającym podstawienia chromu, manganu, niklu i krzemu, a cząstki stopu $\mathrm{Cr}_{0,18} \mathrm{Fe}_{0,09} \mathrm{Ni}_{0,73}$ również zawierają niewielkie ilości manganu i krzemu (tab.VI). Pył ze spawania stali nierdzewnej zawiera związki o udowodnionym charakterze kancerogennym; związki chromu(VI) i związki niklu. Analiza chemiczna pyłu powstającego przy spawaniu profili wykonanych ze stali ocynkowanej E370 ZF 140 prowadzona pod kątem głównych składników wykazała, że w pyle występują związki cynku, żelaza, manganu, glinu i krzemu (rys. 4). W chemicznej identyfikacji fazowej pyłu rozpoznano składniki fazowe: cynk metaliczny $\mathrm{Zn}$, tlenek cynku ZnO, magnetyt $\mathrm{Fe}_{3} \mathrm{O}_{4}$, franklinit $\mathrm{ZnFe}_{2} \mathrm{O}_{4}$, fluorek baru $\mathrm{BaF}_{2}$, żelazo metaliczne a-Fe, peryklaz - tlenek magnezu MgO, oraz stwierdzono, że mangan i glin oraz magnez występują we franklinicie - $(\mathrm{Zn}, \mathrm{Mn}, \mathrm{Mg})(\mathrm{Fe}, \mathrm{Al})_{2} \mathrm{O}_{4}$ (tab.VII). Pył wydzielający

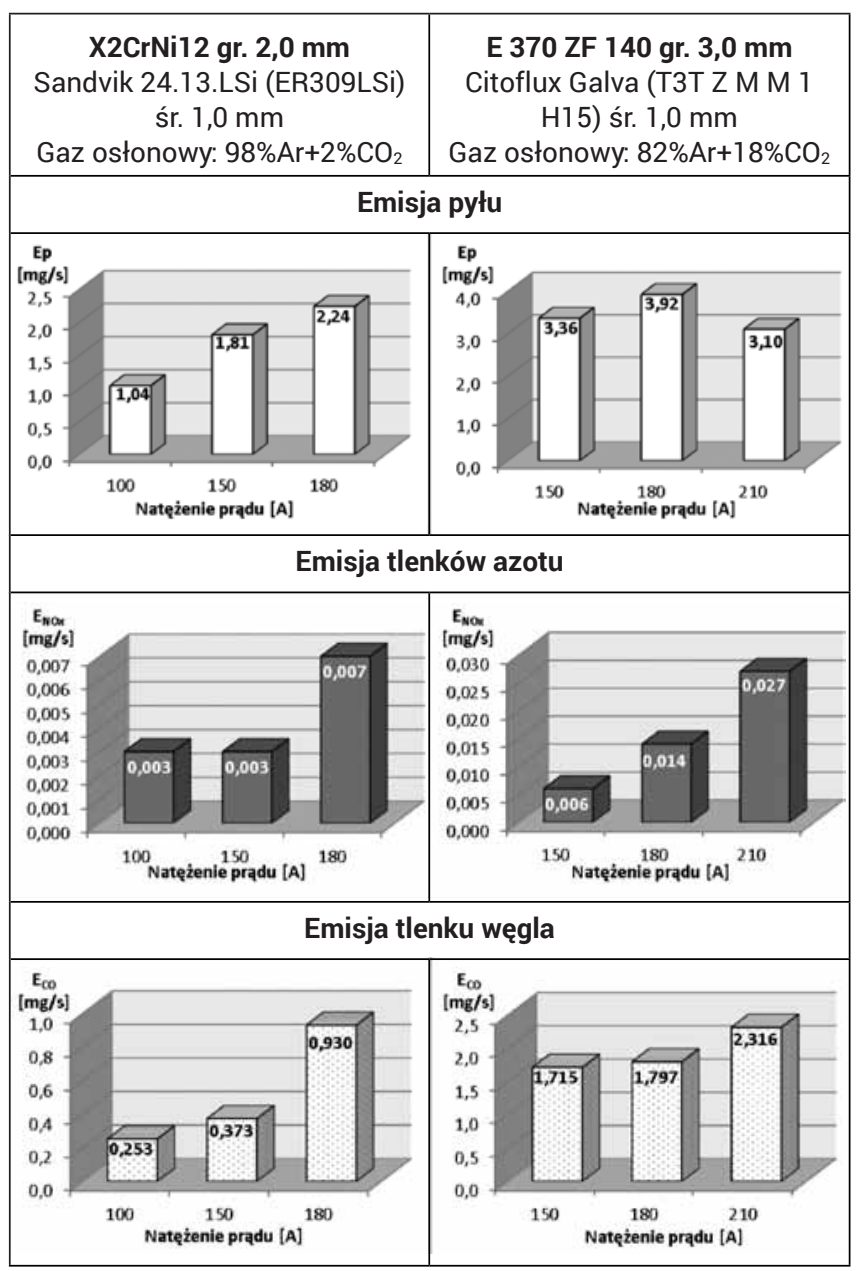

Rys. 2. Emisja pyłu całkowitego, tlenków azotu i tlenku węgla przy spawaniu metodą MAG profili ze stali nierdzewnej ferrytycznej w gat. X2CrNi12 i stali niestopowej z powłoką cynkową w gat. E 370 ZF 140 [18]

Fig. 2. Emission of fume, nitrogen oxides and carbon monoxide during MAG welding of stainless ( $\mathrm{X} 2 \mathrm{CrNi12}$ grade) and unalloyed zinc coated steel (E 370 ZF140 grade) components [18] się ze spawania profili wykonanych ze stali ocynkowanej E370 ZF 140 z zastosowaniem drutu proszkowego z rdzeniem metalowym typu Citoflux Galva (T3T Z M M 1 H15) zawiera substancje chemiczne, które w wyniku narażenia mogą powodować gorączkę metaliczną. Taka sytuacja zdrowotna może zaistnieć w momencie kiedy na stanowiskach pracy będą przekroczone wartości najwyższych dopuszczalnych stężeń zanieczyszczeń Dodatkowo w pyle pochodzącym z procesu spawania stali ocynkowanej E370 ZF 140 z zastosowaniem drutu proszkowego z rdzeniem metalowym wykazano obecność związków pochodzących ze spoiwa tj.: związki manganu i glinu oraz związek baru - fluorek baru $\mathrm{BaF}_{2}$. Wszystkie te związki należą do substancji szkodliwych. Fluorek baru zaliczany jest do substancji o toksyczności ostrej dla układu oddechowego, został sklasyfikowany w kategorii $4 \mathrm{w}$ rozporządzeniu Parlamentu Europejskiego i Rady (WE) nr 1272/2008 w sprawie klasyfikacji, oznakowania i pakowania substancji i mieszanin, [19].

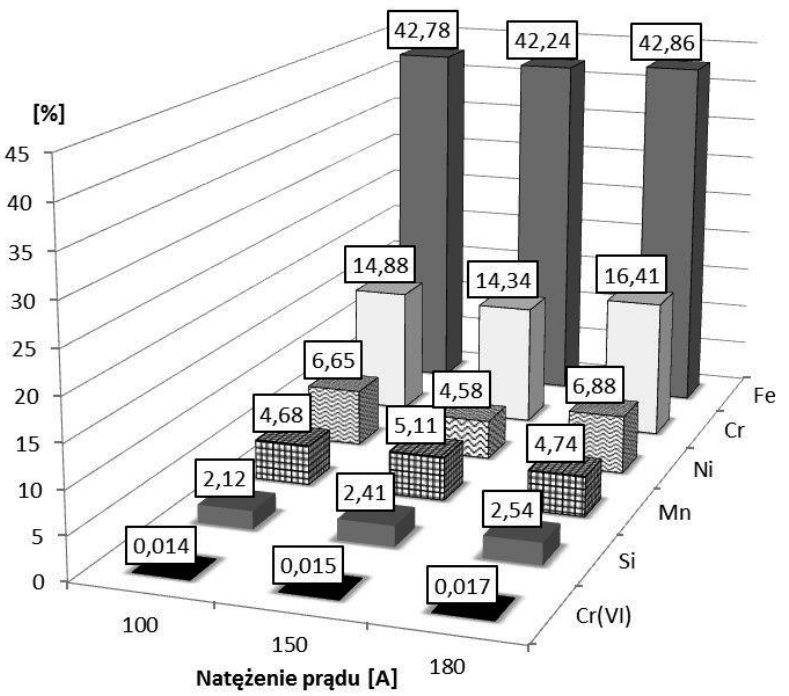

Rys. 3. Skład chemiczny pyłu powstającego przy spawaniu metodą MAG profili ze stali w gat. X2CrNi12, drut elektrodowy Sandvik 24.13.LSi (ER309LSi), gaz osłonowy: $98 \% \mathrm{Ar}+2 \% \mathrm{CO}_{2}$. Zakres prądu spawania: 100-180 A [18]

Fig. 3. Chemical composition of fume generated while MAG welding X2CrNi12 grade steel shapes using a Sandvik 24.13.LSi (ER309LSi), shielding gas: $98 \% \mathrm{Ar}+2 \% \mathrm{CO}_{2}$; welding current range: $100-180 \mathrm{~A}$ [18]

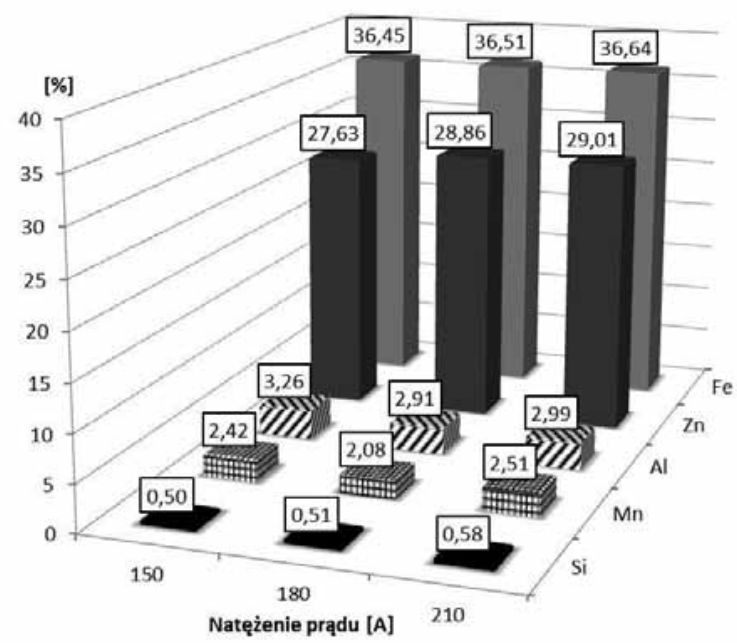

Rys. 4. Skład chemiczny pyłu powstającego przy spawaniu metodą MAG profili ze stali w gat. E 370 ZF140, drut proszkowy Citoflux GaIva (T3T Z M M $1 \mathrm{H} 15$ ), gaz osłonowy: $82 \% \mathrm{Ar}+18 \% \mathrm{CO}_{2}$. Zakres prądu spawania: 150-210 A [18]

Fig. 4. Chemical composition of fume generated while $M A G$ welding $E$ 370ZF140 grade steel shapes using a Citoflux Galva (T3TZM M 1 H15) flux cored wire, shielding gas: $82 \% \mathrm{Ar}+18 \% \mathrm{CO}_{2}$; welding current range: $150-210$ A [18] 
Tablica VI. Identyfikacja fazowa i ilościowa analiza fazowa pyłu przy spawaniu metodą MAG profili ze stali X2CrNi12, drut elektrodowy Sandvik 24.13.LSi (ER309LSi)[18]

Table VI. Phase identification and phase quantitative analysis of fume generated while MAG welding X2CrNi12 grade steel shapes using a Sandvik 24.13.LSi (ER309LSi) electrode [18]

\begin{tabular}{|c|c|c|c|c|c|c|c|c|c|}
\hline \multirow{2}{*}{$\begin{array}{c}\text { Materiał } \\
\text { podstawowy }\end{array}$} & \multicolumn{3}{|c|}{ Parametry technologiczne procesu } & \multicolumn{5}{c|}{ Skład chemiczny [\%] } \\
\cline { 2 - 11 } & $\mathrm{I}[\mathrm{A}]$ & $\mathrm{U}[\mathrm{V}]$ & $\begin{array}{c}\mathrm{Vdr} \\
{[\mathrm{m} / \mathrm{min}]}\end{array}$ & $\begin{array}{c}\mathrm{Vsp} \\
{[\mathrm{mm} / \mathrm{min}]}\end{array}$ & $\mathrm{Fe}_{3} \mathrm{O}_{4}$ & $\mathrm{Fe}_{2} \mathrm{O}_{3}$ & $\mathrm{a}-\mathrm{Fe}$ & $\mathrm{Cr}_{0,18} \mathrm{Fe}_{0,09} \mathrm{Ni}_{0,73}$ & $\mathrm{CrO}_{3}$ \\
\hline \multirow{3}{*}{$\mathrm{X} 2 \mathrm{CrNi12}$} & 100 & 17,73 & 5,8 & 380 & $87,3 \pm 0,2$ & $1,9 \pm 0,2$ & $8,9 \pm 0,2$ & $1,9 \pm 0,2$ & śladowe ilości \\
\cline { 2 - 11 } & 150 & 22,03 & 8,5 & 600 & $94,4 \pm 0,2$ & & $4,8 \pm 0,2$ & $0,8 \pm 0,2$ & śladowe ilości \\
\cline { 2 - 11 } & 180 & 27,67 & 9,7 & 1110 & $99,5 \pm 0,2$ & & $0,5 \pm 0,2$ & & śladowe ilości \\
\hline
\end{tabular}

Tablica VII. Identyfikacja fazowa i ilościowa analiza fazowa pyłu powstającego przy spawaniu metodą profili stalowych w gatunku E370 ZF140 drutem proszkowym Citoflux Galva (T3T Z M M 1 H15) o średnicy $1,0 \mathrm{~mm}$. Gaz osłonowy: $82 \% \mathrm{Ar}+18 \% \mathrm{CO}_{2}$ [18]

Table VII. Phase identification and phase quantitative analysis of fume generated while MAG welding E370 ZF140 grade steel shapes using a Citoflux Galva (T3T Z M M $1 \mathrm{H} 15$ ) flux-cored wire, shielding gas: $82 \% \mathrm{Ar}+18 \% \mathrm{CO}_{2}[18]$

\begin{tabular}{|c|c|c|c|c|c|c|c|c|c|c|c|}
\hline \multirow{2}{*}{$\begin{array}{c}\text { Materiał } \\
\text { podstawowy }\end{array}$} & \multicolumn{4}{|c|}{ Parametry technologiczne procesu } & \multicolumn{7}{|c|}{ Skład chemiczny [\%] } \\
\hline & $\mathrm{I}[\mathrm{A}]$ & $\mathrm{U}[\mathrm{V}]$ & $\begin{array}{c}\mathrm{Vdr} \\
{[\mathrm{m} / \mathrm{min}]}\end{array}$ & $\begin{array}{c}\text { Vsp } \\
{[\mathrm{mm} / \mathrm{min}]}\end{array}$ & Zn & $\mathrm{ZnO}$ & $\mathrm{Fe}_{2} \mathrm{O}_{3}$ & $\mathrm{ZnFe}_{2} \mathrm{O}_{4}$ & $\mathrm{BaF}_{2}$ & $\mathrm{a}-\mathrm{Fe}$ & $\mathrm{MgO}$ \\
\hline \multirow{3}{*}{$\mathrm{X} 2 \mathrm{CrNi12}$} & 100 & 17,73 & 5,8 & 380 & $30,1 \pm 0,3$ & $12,5 \pm 0,3$ & $15,0 \pm 0,3$ & $3,0 \pm 0,3$ & $11,4 \pm 0,2$ & $0,7 \pm 0,2$ & $27,3 \pm 0,6$ \\
\hline & 150 & 22,03 & 8,5 & 600 & $15,5 \pm 0,2$ & $22,7 \pm 0,2$ & $3,5 \pm 0,2$ & $7,0 \pm 0,2$ & $11,9 \pm 0,2$ & $0,6 \pm 0,2$ & $38,8 \pm 0,3$ \\
\hline & 180 & 27,67 & 9,7 & 1110 & $6,3 \pm 0,2$ & $23,5 \pm 0,3$ & $22,2 \pm 0,2$ & $4,0 \pm 0,2$ & $8,5 \pm 0,1$ & $0,8 \pm 0,1$ & $34,7 \pm 0,5$ \\
\hline
\end{tabular}

Przeprowadzone badania laboratoryjne emisji zanieczyszczeń przy spawaniu metodą MAG elementów wykonanych z dwóch różnych gatunków stali; stali nierdzewnej i stali niestopowej w powłoką typu ZF, pozwoliły na porównanie w aspekcie zagrożeń pyłowych i gazowych warunków pracy spawaczy przy wytwarzaniu wyrobów spawanych wykonanych z badanych materiałów. Emisja czasowa pyłu całkowitego i gazów powstających przy spawaniu profili wykonanych ze stali ocynkowanej E370 ZF140 była w całym badanym zakresie prądowo-napięciowym większa w porównaniu ze spawaniem profili wykonanych ze stali X2CrNi12. $\mathrm{Na}$ stanowiskach pracy przy spawaniu stali ocynkowanej oraz stali nierdzewnej może wystąpić przekroczenie obowiązujących wartości najwyższych dopuszczalnych stężeń zanieczyszczeń. Przekroczenie wartości NDS dla pyłu i gazów w przypadku spawania elementów ze stali z powłokami cynkowanymi może wystąpić w znacznie krótszym czasie ekspozycji pracownika na dym spawalniczy w porównaniu do analogicznych warunków pracy przy spawaniu elementów ze stali nierdzewnej. Stwierdzenie przekroczenia NDS i jego krotności jest oczywiście możliwe jedynie w trakcie badań środowiskowych przeprowadzonych na każdym stanowisku spawalniczym. Badania środowiskowe przy spawaniu stali ocynkowanej z powłokami ochronnymi przy zastosowaniu drutów proszkowych powinny obejmować określenie stężenia pyłu całkowitego, pyłu respirabilnego, stężenia gazów (NOx i CO) oraz określenie stężenia głównych składników chemicznych pyłu: związki cynku, żelaza, manganu, glinu i krzemu oraz fluorku baru BaF2, jeżeli jego zawartość w drucie proszkowym jest podana przez producenta w karcie charakterystyki ( Safety Data Sheet). Z uwagi na wysoką emisję zanieczyszczeń oraz skład chemiczny powstających zanieczyszczeń przy spawaniu elementów wykonanych ze stali ocynkowanej może zaistnieć potrzeba zmiany stosowanego systemu wentylacji stanowiskowej i wentylacji ogólnej hali technologicznej. W celu zobrazowania intensywności wydzielania się dymu spawalniczego podczas spawania profili wykonanych MAG ze stali ocynkowanej z zastosowaniem drutu proszkowego z rdzeniem metalowym na rysunku 5 przedstawiono zdjęcia ze stanowiska badawczego.
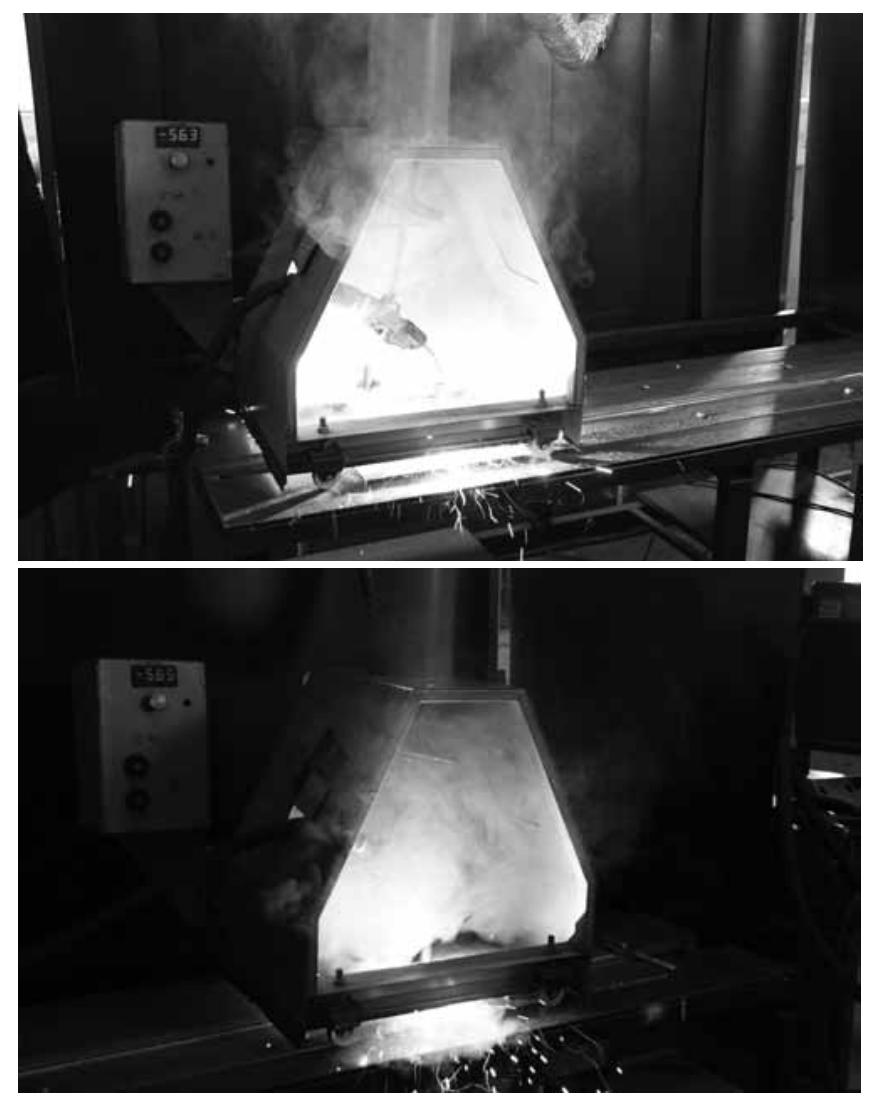

Rys. 5. Intensywność wydzielania się dymu spawalniczego podczas spawania na stanowisku badawczym profili wykonanych MAG ze stali ocynkowanej E370 ZF 140 z zastosowaniem drutu proszkowego z rdzeniem metalowym typu Citoflux Galva. Parametry technologiczne: I=210 A, U=20,5 V, Vdr $=7,5[\mathrm{~m} / \mathrm{min}], \mathrm{Vsp}=560[\mathrm{~mm} /$ $\mathrm{min}]$. W celu zobrazowania intensywności powstawania dymu spawalniczego zdjęcia wykonano przy otwartej komorze pyłowej

Fig. 5. Welding fume emission intensity while MAG welding shapes made of E370 ZF 140 galvanised steel using a Citoflux Galva metallic flux-cored wire. Technological parameters: $I=210 \mathrm{~A}, \mathrm{U}=20,5$ $\mathrm{V}, \mathrm{Vdr}=7,5[\mathrm{~m} / \mathrm{min}], \mathrm{Vsp}=560[\mathrm{~mm} / \mathrm{min}]$. In order to demonstrate welding fume generation intensity, the photographs were made with the fume chamber open 


\section{Wnioski}

Przy spawaniu elementów ze stali ocynkowanej E370 ZF140 metodą MAG z zastosowaniem drutu proszkowego emisja do środowiska pracy pyłu całkowitego oraz tlenków azotu i tlenku węgla była kilkukrotnie większa w porównaniu do spawania elementów ze stali nierdzewnej X2CrNi12 z zastosowaniem drutu litego.

Pył wydzielający się przy spawaniu elementów wykonanych ze stali ocynkowanej E370 ZF140 zawiera substancje chemiczne, które w wyniku narażenia mogą powodować gorączkę metaliczną. Substancje te należą do grupy substancji szkodliwych o działaniu toksycznym.

Na stanowiskach pracy przy spawaniu elementów ze stali ocynkowanej oraz stali nierdzewnej może wystąpić przekroczenie obowiązujących wartości najwyższych dopuszczalnych stężeń zanieczyszczeń. Przekroczenie wartości NDS dla pyłu i gazów w przypadku spawania elementów ze stali z powłokami cynkowanymi może wystąpić w znacznie krótszym czasie ekspozycji pracownika na dym spawalniczy w porównaniu do analogicznych warunków pracy przy spawaniu elementów ze stali nierdzewnej.

\section{Literatura}

[1] Matczak W., Gromiec J.P.: Zasady oceny narażenia spawaczy na dymy i gazy, wyd. Instytut Medycyny Pracy im. J. Nofera, Łódź 2003.

[2] Voitkevich V.: Welding Fumes. Formation, properties and biological effects, Abington Publishing, Cambridge 1995.

[3] Matusiak J., Wyciślik J.: Zdrowie i bezpieczeństwo przy produkcji spawalniczej. Biuletyn Instytutu Spawalnictwa nr 3/2009.

[4] Matusiak J., Wyciślik A.: Spawanie stali nierdzewnych w aspekcie zagrożeń zdrowia i bezpieczeństwa pracy spawaczy. Hutnik. Wiadomości hutnicze $\mathrm{nr}$ 10/2007.

[5] Redding C.: Fume model for gas metal arc welding, Welding Journal, Welding Research Supplement $\mathrm{nr}$ 6/2002.

[6] Moreton J., Stiller K.R.: Fume emission characteristics of stainless steel MIG.MAG welding. IIW Doc. VIII-1458-89.

[7] Matusiak J., Rams B.: Emission of dust and gases in tubular cored wire welding of steel, International Journal of Occupational Safety and Ergonomics t. 9, $\mathrm{nr} 3 / 2003$.

[8] Matusiak J.: Zagrożenia zdrowia spawaczy podczas spawania stali nierdzewnych, Przegląd Spawalnictwa nr 3/2008.

[9] Matusiak, Wyciślik J. i in.: „Analiza wpływu warunków technologicznych innowacyjnych technik spajania różnych materiałów konstrukcyjnych z nowoczesnymi powłokami ochronnymi na stan środowiska pracy. Badanie emisji substancji organicznych przy zgrzewaniu rezystancyjnym punktowym różnych materiałów konstrukcyjnych." Praca badawcza IS Ma-34/2011.

[10] Wittczak T., Walusiak J., Pałczyński C.: Choroby układu oddechowego u spawaczy (Welding-related respiratory diseases), Medycyna Pracy 2009;60(3).
[11] Ashby H.S.: Welding fume in the workplace. Preventing potential health problems through proactive controls. Occupational Safety-Professional safety no. 04/2002.

[12] Lyngenbo O.; Groth S.; Groth M.; Olsen O.; Rossing N.: Occupational lung function impairment in never smoking Danish welders. Scandinavian Journal of Social Medicine. 198917(2).

[13] Spiegel-Ciobanu V.E.: Chromium and nickel in welding and allied processes-some important aspects, IIW Doc. VIII 1799-97.

[14] Cunat P.J.: Chromium in stainless steel welding fumes, IIW Doc.VIII1973-03.

[15] McMillan G.: Lung cancer and electric arc welding, IIW Doc.1988-05

[16] Marini F.: Does welding stainless steel cause cancer? IIW Doc. VIII 1767-95.

[17] Sjogern B.: Exposure to stainless steel welding fumes and lung cancer, IIW Doc. VIII 1748-94

[18] Matusiak J., Pfeifer T., Wyciślik J., Kiszka A.: Spawanie profili i blach ze stali niestopowej z cynkową powłoką ochronną - studium i badania rozpoznawcze, Praca badawcza IS, Da-21/2015.

[19] Rozporządzenie Parlamentu Europejskiego i Rady (WE) nr 1272/2008 z dnia 16 grudnia 2008 r. w sprawie klasyfikacji, oznakowania i pakowania substancji i mieszanin, zmieniające i uchylające dyrektywy 67/548/EWG i 1999/45/WE oraz zmieniające rozporządzenie (WE) nr 1907/2006. 